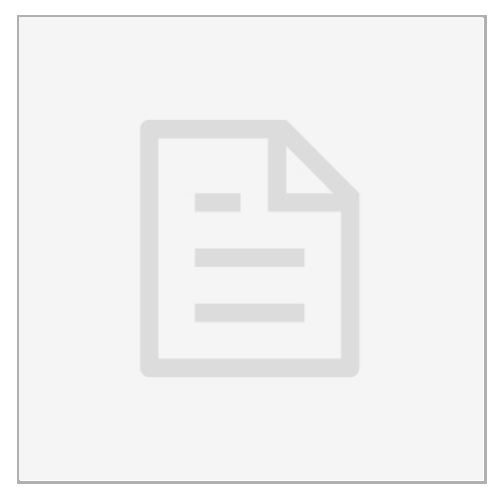

\title{
(3) Transformation and Preparation of Chemically Competent Bacillus subtilis cells
}

Igem Dusseldorf ${ }^{1}$

${ }^{1}$ Heinrich-Heine Universität Düsseldorf

Igem Dusseldorf

OCT 18, 2019

\section{open ठaccess}

\section{DOI:}

dx.doi.org/10.17504/protocol s.io.8fvhtn6

\section{Protocol Citation: Igem} Dusseldorf 2019.

Transformation and Preparation of Chemically Competent Bacillus subtilis cells. protocols.io https://dx.doi.org/10.17504/p rotocols.io.8fvhtn6

License: This is an open access protocol distributed under the terms of the Creative Commons Attribution License, which permits unrestricted use, distribution, and reproduction in any medium, provided the original author and source are credited

Protocol status: Working We use this protocol and it's working

Created: Oct 18, 2019

Last Modified: Oct 18, 2019

PROTOCOL integer ID: 28885

Preparation of Chemically Competent Bacillus subtilis cells 
For $20 \mathrm{ml}$ or $50 \mathrm{ml}$ PARIS-Medium mix:

\begin{tabular}{|c|c|c|c|}
\hline final concentration & Stock & $\begin{array}{l}\text { for } 50 \\
\mathrm{ml}\end{array}$ & $\begin{array}{l}\text { for } 20 \\
\mathrm{ml}\end{array}$ \\
\hline \multicolumn{4}{|c|}{$\begin{array}{l}100 \mathrm{mM} \text { potassium phosphate buffer } \\
\mathrm{pH} 7.0\end{array}$} \\
\hline 60 mM K2HPO4 & $\begin{array}{l}1 \mathrm{M} \\
(3.48 \\
\mathrm{g} \text { in } \\
20 \mathrm{ml} \\
\text { for } \\
\text { stock) }\end{array}$ & $3 \mathrm{ml}$ & $1.2 \mathrm{ml}$ \\
\hline $40 \mathrm{mM} \mathrm{KH} 2 \mathrm{PO} 4$ & $\begin{array}{l}0.5 \mathrm{M} \\
(1.36 \\
\mathrm{g} \text { in } \\
20 \mathrm{ml} \\
\text { for } \\
\text { stock) }\end{array}$ & $4 \mathrm{ml}$ & $1.6 \mathrm{ml}$ \\
\hline $3 \mathrm{mM}$ trisodium citrate & $\begin{array}{l}0.5 \mathrm{M} \\
(0.73 \\
5 \mathrm{~g} \mathrm{in} \\
5 \mathrm{ml})\end{array}$ & $300 \mu \mathrm{l}$ & $120 \mu \mathrm{l}$ \\
\hline 20 mM Potassium-L-glutamate & \begin{tabular}{|l|}
$1 \mathrm{M}$ \\
$(4.06$ \\
$\mathrm{g}$ in \\
20 \\
$\mathrm{ml})$ \\
\end{tabular} & $1 \mathrm{ml}$ & $400 \mu \mathrm{l}$ \\
\hline $21 \mathrm{mM} \mathrm{MgSO} 4$ & $\begin{array}{l}1 \mathrm{M} \\
(1.23 \\
\mathrm{g} \text { in } 5 \\
\mathrm{ml})\end{array}$ & $\begin{array}{l}1050 \\
\mu l \\
(7 x)\end{array}$ & $\begin{array}{l}420 \mu l \\
(7 x)\end{array}$ \\
\hline $1 \%$ Glucose & $\begin{array}{l}50 \% \\
(10 \mathrm{~g} \\
\text { in } 20 \\
\mathrm{ml})\end{array}$ & $1 \mathrm{ml}$ & $400 \mu \mathrm{l}$ \\
\hline 20 mg/ml L-Tryptophan & \begin{tabular}{|l}
5 \\
$\mathrm{mg} / \mathrm{m}$ \\
$\mathrm{l}(25$ \\
$\mathrm{mg}$ in \\
$5 \mathrm{ml})$
\end{tabular} & $200 \mu \mathrm{l}$ & 80 \\
\hline $0.1 \%$ Caseinhydrolysat (DIFCO!) & $\begin{array}{l}10 \% \\
(1 \mathrm{~g} \text { in } \\
10 \\
\mathrm{ml})\end{array}$ & $500 \mu \mathrm{l}$ & $200 \mu \mathrm{l}$ \\
\hline
\end{tabular}

2 Inoculation of precultures: Spread B. subtilis from Glycerol stock on LB plate and incubate over night for $37^{\circ} \mathrm{C}$ or over the weekend at $30^{\circ} \mathrm{C}$. 
3 Resuspend single clones in $5 \mathrm{ml}$ Paris Medium (test tube) on incubator roller or plate washer with $1 \mathrm{ml}$ Paris Medium (saves one day work)

4 Inoculation of $2.5 \mathrm{ml}$ Paris Medium (test tube) from pre-culture (wash or liquid-overnight culture) to $\mathrm{OD}_{580}=0.2$

$5 \quad 4$ h incubation on incubator roller at $37^{\circ} \mathrm{C}$

6 Centrifuge $1 \mathrm{ml}$ pellet cells in reaction tubes for $1 \mathrm{~min}$ at maximum speed. Remove the supernatant.

7 Resuspend the pellet in $1 \mathrm{ml}$ Paris medium with $10 \%(\mathrm{v} / \mathrm{v})$ glycerol.

8 Store $100 \mu$ l aliquots at $-80^{\circ} \mathrm{C}$

\section{Transformation of Bacillus subtilis}

9 Thaw aliquots at $37^{\circ} \mathrm{C}$, add $900 \mu \mathrm{l}$ Paris medium and 500-1000 ng plasmid DNA (test tube)

10 Incubate $6 \mathrm{~h}$ in the incubator roller at $37^{\circ} \mathrm{C}$ 
11 Pellet cells, remove $800 \mu \mathrm{l}$, resuspend and plate the rest (for normal transformation on LB+antibiotic) 